\title{
Quality Function Deployment Implementation in Construction: A Systematic Literature Review
}

\begin{abstract}
The construction of new buildings represents a significant investment. The goal of new building construction is to maximize value and minimize cost while staying on time and within budget. Translating customer requirements into engineering terms for new construction design is vital for a construction project to be successful. Quality function deployment has been successfully used in product development to capture the voice of the customer and translate it into engineering characteristics. Quality function deployment then carries these parameters into production and service to ensure the voice of the customer is being met with the final product. The house of quality, a tool within quality function deployment, can provide a means for comparison of owner's project requirements and the proposed design, along with identifying how the design decisions impact meeting customer requirements and green building requirements. Quality function deployment can effectively link the project phases through design and construction and into operations and maintenance to ensure the owner's project requirements are met with the final building. This research identifies and categorizes studies of quality function deployment applications in construction. The research method used is a systematic literature review from databases related to quality function deployment in the construction industry published in the periodicals through 2016. The principal findings of implementations, practices, and integrated approaches are then summarized. This article intends to propel further research of quality function deployment in the construction sector.
\end{abstract}

Keywords: construction, engineering management, quality function deployment, systematic review

Manuscript received May 30, 2016; accepted August 10, 2016

Elizabeth A. Cudney (凶)

Department of Engineering Management and Systems Engineering, Missouri University of Science and Technology, Rolla, MO 65409, USA Email: cudney@mst.edu

William L. Gillis

Department of Civil, Architectural, and Environmental Engineering, Missouri University of Science and Technology, Rolla, MO 65409, USA

\section{Introduction}

Global construction continues to steadily increase with a $2.4 \%$ increase from 2012 to 2013 (IHS, 2013) and is expected to increase annually by $3.9 \%$ over the next 15 years (Global Construction Perspectives and Oxford Economics, n.d.). According to Caulfield (2015), the United States, China, and India will account for $57 \%$ of global construction growth through 2030. Further, construction output is expected to expand by $85 \%$ to $\$ 15.5 \times 10^{12}$ internationally in 2030 . With the forecasted growth in the construction industry, it is important that this global industry continues to meet and/or exceed customer expectations while meeting government and housing regulations.

Customers continue to expect more reliable, durable products and services in a timely manner. To respond to customers changing needs and expectations, it is imperative for organizations to frequently gather and analyze the voice of the customer (VOC). The VOC represents the desires and requirements of the customer at all levels, which is translated into engineering characteristics and functions for the development of new products and services. Failure to gather the VOC from key stakeholders frequently can lead to the development of products and services that do not satisfy customer needs and requirements. Therefore, translating the VOC into product characteristics is vital for a company to remain competitive.

Quality function deployment (QFD) is a system for translating customer requirements into appropriate product or service requirements at each stage of product development from market research to engineering, manufacturing, marketing/sales, and distribution by utilizing the VOC throughout the process (Stanley, Elrod, Cudney, \& Fisher, 2015). Dr. Akao developed QFD in 1966 in Japan, which was first implemented in Mitsubishi's Kobe shipyard in 1972. Clausing (1994) expanded the QFD methodology by developing a four-phase QFD model to carry the VOC from the high-level system to monitoring the product in production. The four phases consisted of the house of quality, part deployment, process planning, and operations 
planning.

After the introduction of QFD in Japan, the methodology was mainly used in manufacturing in the United States (Chan and $\mathrm{Wu}, 2002$ ). However, the use of QFD expanded considerably and is now used widely in product development (Cristiano, Liker, \& White, 2000; Karsak, Sozer, \& Alptekin, 2003; Zairi and Youssef, 1995), service development (Cudney, Elrod, \& Uppalanchi, 2012; Jeong \& Oh 1998; Paryani, Masoudi, \& Cudney, 2010), and educational design (Ezzell, Cudney, Mazur, \& Phelps, 2016; Mazur, 1996; Sahney, Banwet, \& Karunes, 2006). QFD provides a structured, team approach to understanding customer requirements, which, in turn, leads to increased customer satisfaction. In addition, by understanding and integrating the voice of the customer into product and service design, organizations can significantly reduce the time to market, number of design changes, and development costs while providing and documenting innovative design solutions (Cudney \& Agustiady, 2016). The house of quality (HOQ) is a tool within the QFD process which provides a means of matching the product's design with the voice of the custumer or customer requirements. There are seven key steps in creating the house of quality as outlined in Table 1.

These steps provide the general framework for the HOQ as shown in Figure 1. Customer requirements are "what"

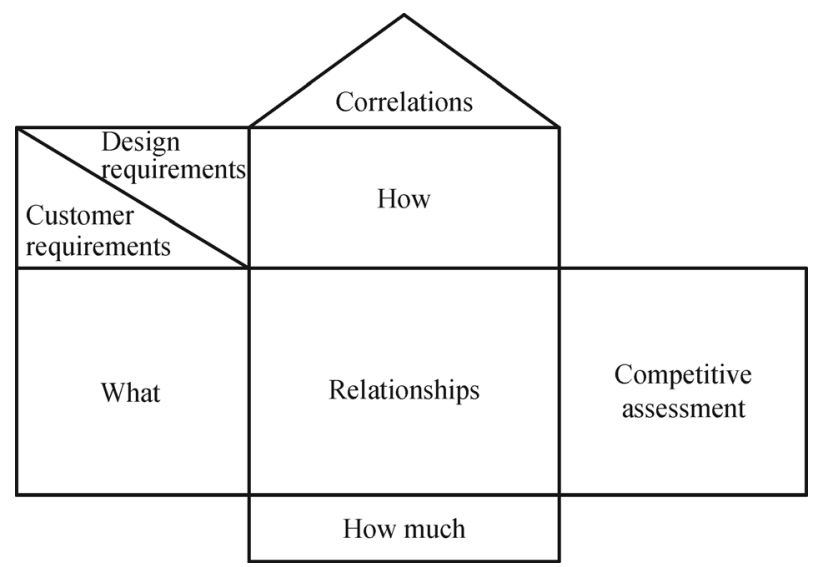

Figure 1. House of Quality. the customer desires of a particular product based on marketing studies. The design response is "how" the designers will meet the needs of the customer. Design correlations are used as a means of understanding if one design response has an impact on another design response. The body of the matrix holds the relationships, or how well each design response addresses the customer requirements. The marketing matrix and design data matrix are used by the marketing and design teams for developing and prioritizing the "whats" and "hows." In short, QFD is designed to gather the customer's needs and desires of a product, weigh those needs and desires against the needs and desires of the company, verify that engineering designs the product to those requirements, and verify that manufacturing can produce the product as designed (Singh, Elrod, \& Cudney, 2012). The goal is a product that will appeal to as many customers as possible.

\section{Methodology}

The aim of this research was to review the existing literature regarding the use of quality function deployment in the construction industry and provide the findings of the systematic review. A four phase approach, adopted by Tranfield, Denyer, and Smart (2003), was employed for the systematic review as illustrated in Table 2 .

In the planning phase, the context-intervention-mechanism-output (C-I-M-O) framework (Denyer \& Tranfield, 2009) was employed to develop the review questions and determine the scope of the review as shown in Table 3. Based on the research goals, the terms 'construction' and 'quality function deployment' were used to search for articles.

Since quality function deployment is a relatively new topic, the sampling phase was conducted without a date range. There are numerous sources that outline the quality function deployment methodology; however, little exists on the application of QFD in the construction industry and how it benefits industry practitioners. The sampling phase employed the following databases: Google Scholar,

Table 1

Steps for Creating the House of Quality

\begin{tabular}{ll}
\hline Step & Description \\
\hline 1 & Determine what the customer wants. These are known as the "whats" \\
3 & Conduct a competitive assessment to determine how well the organization meets the customer requirements compared to the competition \\
4 & $\begin{array}{l}\text { Determine the key focus for designing the product or service based on the competitive assessment } \\
\text { Develop methods to measure or control the product, process, or design to ensure customer requirements are consistently met. These are known as } \\
\text { the "hows" } \\
\text { Evaluate the proposed design requirements (hows) against the customer requirements (whats). This is performed in the relationship matrix } \\
7\end{array} \quad \begin{array}{l}\text { Evaluate the design tradeoffs. This is performed in correlations matrix or "roof" of the house of quality } \\
\text { Determine the key design requirements that should be focuses on. This is in the "basement" of the house of quality and is commonly referred to as }\end{array}$ \\
\hline
\end{tabular}


Table 2

Systematic Review Phases

\begin{tabular}{|c|c|c|c|}
\hline Phase & Phase description & Phase steps & Output \\
\hline 1. Planning & $\begin{array}{l}\text { The research aim, objectives, and scope are outlined based on } \\
\text { the research topic, time, cost, and quality }\end{array}$ & $\begin{array}{l}\text { 1) Determine the systematic review objectives } \\
\text { and scope } \\
\text { 2) Screen key articles based on scope }\end{array}$ & Review protocol \\
\hline 2. Sampling & $\begin{array}{l}\text { The literature is searched using the review protocol to provide a } \\
\text { transparent repeatable search }\end{array}$ & $\begin{array}{l}\text { 1) Search the articles } \\
\text { 2) Select the articles }\end{array}$ & Selected relevant articles \\
\hline 3. Analyzing & $\begin{array}{l}\text { Data and evidence are pulled from the selected sources and } \\
\text { categorized to produce explanations or theories for the various } \\
\text { findings }\end{array}$ & $\begin{array}{l}\text { 1) Data extraction } \\
\text { 2) Data coding }\end{array}$ & $\begin{array}{l}\text { Descriptive analysis and } \\
\text { future research agenda }\end{array}$ \\
\hline 4. Reporting & $\begin{array}{l}\text { The systematic review report documents the review process } \\
\text { which enables repeatability of the review }\end{array}$ & $\begin{array}{l}\text { 1) Write the report detailing the review process, } \\
\text { results, analysis, and gaps } \\
\text { 2) Document evidence into practice. }\end{array}$ & Systematic review report \\
\hline
\end{tabular}

Table 3

C-I-M-O Framework

\begin{tabular}{lcc}
\hline Planning steps & Review questions & Scope \\
\hline Context & Which relationships, institutional settings, or wider systems are & Construction industry \\
being studied? & & \\
Intervention & Which effects of the events, actions, or activities are being studied? & Quality function deployment, house of quality \\
Mechanism & What are the mechanisms that explain the relationship between & House of quality implementation process \\
interventions and outcomes? & What are the effects of the interventions? & Benefits, barriers, limitations, motivation \\
\hline
\end{tabular}

Emerald Insight, IEEEXplore, and Science Direct. Using the terms 'construction' and 'quality function deployment,' a total of 1,299 articles were identified as potentially relevant for the study. The articles were then selected based on three inclusion/exclusion criteria. For the article to be included it must be a peer reviewed publication, the context must be the construction industry, and the paper must be in English. Based on these criteria, 14 journal papers, 3 conference papers, and one book chapter were included in the study.

\subsection{Quality function deployment in construction}

While the literature is limited on the application of the quality function deployment methodology in the construction industry, the types of construction projects do vary. For example, Liu and Zeng (2012) employed QFD for the design of a marine power plant. Yuventi and Weiss (2013) applied QFD to illustrate variances in decision-making for large-scale photovoltaic system construction projects and found QFD to be robust even with significant degrees of uncertainty. Delgado-Hernandez, Bampton, and Aspinwall (2007) conducted a case study to compare an existing children's nursery to new construction by two competitors that employed QFD to identify and analyze customer requirements. The use of QFD resulted in on-time delivery and higher customer satisfaction. Further, Ahmed, Sang, and Torbica (2003) investigated the application of QFD to the planning and design stage for civil engineering projects. Due to the complexity and extended timelines required for civil engineering capital projects, the study utilized two existing projects to test the use of QFD. Masoudi, Cudney, and Paryani (2013) extended QFD to the construction of the landscape of a new hotel.

Quality function deployment was utilized by Mallon and Mulligan (1993) to prioritize conflicting needs and provide a tool for making more accurate decisions. QFD allowed the design team to create while aligning with the customers' needs and to reduce future changes. An example of applying QFD to construction is presented using a minor renovation of a computer workroom as an example. Initial customer needs were determined and prioritized by customer importance, which were then compared to competitor's workrooms and sales points for each are assigned. Similarly, Dikmen, Birgonul, and Kiziltas (2005) utilized QFD as a strategic decision-making tool during the construction of a high-rise building project. By collecting and verifying customer expectations, the QFD team was able to use QFD to facilitate marketing decisions. Gillis and Cudney (2015a) proposed a methodology to incorporate the VOC throughout the entire construction process using QFD. The research utilized the owner's project requirements (OPR) in place of the VOC.

Abdul-Rahman, Kwan, and Woods (1999) employed QFD to increase customer satisfaction in low-cost housing. In particular, the benefits of reliability in terms of quality, 
cost, and time from the customers' viewpoint were addressed. The research used multiple surveys to prioritize requirements from the customer and various government and housing authorities. Romeo, Smith, Chotipanich, and Pitt (2014) performed a similar study on the benefits of QFD; however, their study focused on the application of QFD for structured product planning and development in developing countries such as Nigeria.

Eldin and Hikle (2003) conducted a pilot study to determine the effectiveness of using QFD in construction projects as a project management tool for the early engineering designs of a large classroom. The study included identifying the customers' needs, organization of the customers' requirements, building the house of quality, and investigating the preliminary designs. The study found that QFD improved communication and the early critical design decisions. However, difficulties experienced by the design team during the process included refining the "what" and "how" into something manageable, agreeing on the evaluation ratings, and determining which items were critical. Eldin and Hikle also offered that QFD should be successful on larger construction projects and the process can minimize construction delays.

The impreciseness and vagueness of design-relevant inputs from the customers led Yang, Wang, Dulaimi, and Low (2003) to propose an integrated approach that combines fuzzy set theory with the house of quality to evaluate the construc tability of a design. The methodology provides a quantitative evaluation in the early design phase. Gillis and Cudney (2015b) extended the QFD methodology to address the complexities of the systems involved in large construction projects with multiple customers for an educational institution. The final project had to address the needs of students, faculty, and staff with office space, advanced research laboratories, and classrooms.

Lee and Arditi (2006) developed a methodology for applying QFD as a qualification system for ranking/ selecting Design/Build firms for construction projects. The proposed methodology included the components and definitions for Service Quality Factors, Corporate Quality Management System, Project Quality Management System, Building Quality Factors, and Building Performance Factors. Data for the study was gathered using survey questionnaires regarding building quality factors and building performance factors which were administered to architecture students. Data from this survey was used to demonstrate how to determine the maximum level of performance in the area of question in order to meet customers' expectations for the construction project.

The topics of sustainability, green buildings, and Leadership in Engineering and Environmental Design (LEED) in construction have gained momentum, several studies have addressed QFD with these studies. Shi and Xie (2009) proposed a methodology that combined fuzzy set theory and QFD to evaluate green construction programs in order to reduce environmental problems. The methodology provided green construction alternatives through a function-cost analysis. Wood, Wang, Abdul-Rahman, and Abdul-Nasir (2016) also employed green construction principles with quality function deployment. They proposed an integrated approach called House of Quality Green Design for the construction of green hospitals, which enabled the determination of demanded qualities by endusers such as safety mechanisms during emergency, use of natural light and ventilation, and materials free from toxicity that were environmentally friendly. In addition, Gillis and Cudney (2014) applied QFD to ensure new construction met LEED guidelines, which promote green, efficient, and sustainable design and construction.

\subsection{Analysis of the literature}

While quality function deployment was developed in 1966 , the literature on implementing QFD in the construction industry does not appear until 1993 and only two papers were published before 2003. Since 1993, 14 peer reviewed publications have appeared. Table 4 provides a listing of the journals for these publications. In addition, the publications by year were analyzed as shown in Figure 2 .

\section{Table 4}

Publications by Journal

\begin{tabular}{lc}
\hline Journal & Number of articles \\
\hline Automation in Construction & 1 \\
Building and Environment & 1 \\
Construction Management and Economics & 1 \\
Engineering Management Journal & 1 \\
Frontiers of Engineering Management & 1 \\
International Journal of Quality \& Reliability Management & 2 \\
Journal of Cleaner Production & 1 \\
Journal of Construction Engineering and Management & 4 \\
Journal of Facilities Management & 1 \\
Quality Management Journal & 1 \\
Book chapter & 1 \\
Conference papers & 3 \\
\hline
\end{tabular}

QFD has been proven within product development and manufacturing; however, little research has been conducted on the use of QFD in construction. The focus of the literature appears to be at the front and back ends of the project.

\subsection{Benefits of using QFD in construction}

QFD was selected by many researchers due to the need for improved safety, reliability, delivery, sustainability (green), and decision-making. Mallon and Mulligan (1993) present QFD as a means for meeting the customers' requirements 


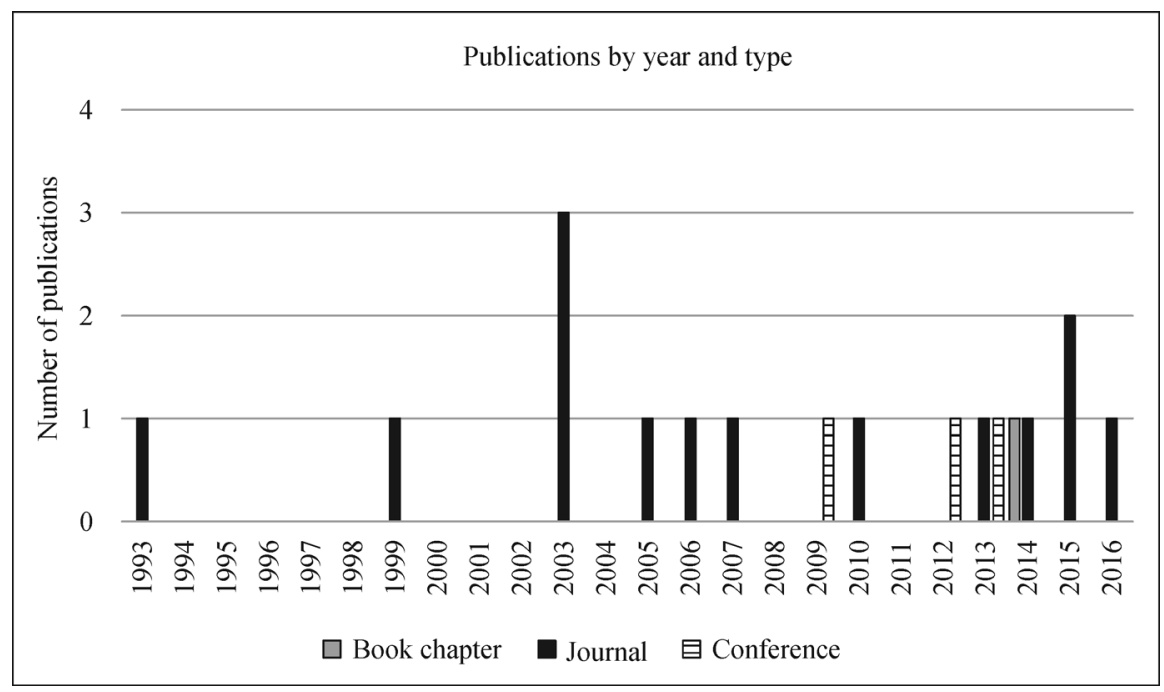

Figure 2. Publications by Year.

in construction projects. They illustrate how the QFD methodology can be used to prioritize conflicting needs and provide a tool for making more accurate decisions. This will allow the design team to be creative with their design concepts, while aligning with the customers' needs and reducing future changes.

Several papers focused on assessing the applicability of QFD in the construction industry. For example, Eldin and Hikle (2003) conducted a pilot study, using the design of a classroom as a case, to determine the effectiveness of using QFD as a means of developing conceptual designs in the preliminary phase of construction projects. This included identifying the customers' needs, organization of the customers' requirements, building the HOQ, and investigating the preliminary designs. The study concluded that QFD provided a means to keep the project moving forward, could eliminate the need to backtrack for design corrections, and should be successful on larger construction projects.

With the trend toward sustainable and green development, several authors merged QFD with green construction and/or LEED principles. Gillis and Cudney (2014), Shi and Xie (2009), and Wood, Wang, Abdul-Rahman, and AbdulNasir (2016) proposed methodologies that combined QFD and green construction programs in order to reduce environmental problems to ensure long-term efficiency and sustainability.

\subsection{Limitations/barriers to use of QFD in construction}

Through the systematic review of the literature several limitations were identified including communication and complexity. The most common complaint was poor communication across all phases of the project. While quality function deployment has been used widely in developing new products and services, its application in the construction industry is not common. QFD has traditionally been used by companies for product development and manufacturing to determine the best design options, manufacturing processes, costs, and level of quality, among others. Hauser and Clausing (1988) asked, "Design is a team effort, but how do marketing and engineering talk to each other?" This is a question that many in the manufacturing industry might answer, "not well." A similar question could be asked within the construction industry, "Design is a team effort, but how does the owner and architect and engineering team talk to each other?" Many in the construction industry might answer the same way, "not well." This is no fault of either party as they typically do not speak the same language. Many owners do not understand the technical jargon of architects and engineers. With product development, marketing is typically adept at determining what the customer might want in a product. With building design, the architect typically has the first contact with the owner. Most architects are proficient with the programming effort required to determine what the building should be; however, much can be missed when it comes to the building systems. Hauser and Clausing (1998) illustrate how quality function deployment and the house of quality can provide a solid method of communication between marketing and engineering, and follows downstream to the manufacturing and quality assurance activities. A similar method using the HOQ can be adapted to the design and construction process.

The complexity of projects also presented limitations with respect to the use of QFD in large construction projects. QFD has been utilized in hotel construction and hotel landscaping. Paryani, Masoudi, and Cudney (2010) utilized QFD to renovate a five-star hotel based on their high-end customers' requirements. These would be 
important features in a new hotel and would certainly have to be considered in a new construction project, but in this case they are looking at the actual hotel guest's desires as the VOC. As a hotel renovation, the project was manageable; however, if the entire hotel design and construction were added the study would be very complex. In another hotel project, Masoudi, Cudney, and Paryani (2013) used QFD for a hotel landscaping design project. Though a very important feature, this is still just a small piece of an entire hotel design. These projects were successful because they represented a subset of larger, more complex projects.

A final, yet key limitation is getting buy-in from the construction industry to implement the QFD methodology. Gathering and analyzing the VOC can be time consuming and expensive. The construction industry, similar to most industries, is short on manpower, funding, and deadlines are tight. With short project durations, it can be difficult to justify the time or money spent upfront. Further, the payback for using QFD can be hard to quantify with numerous schedule and project changes. Linking these changes back to not capturing and analyzing the VOC through QFD is not clear-cut. Also, when QFD is implemented, it can be several years before the project is completed and the results are realized.

\section{Conclusions and future research}

This research provides a systematic review of the application of QFD in the construction industry. Though QFD was created for use in product development and manufacturing, it is well suited for the similar development activities of building design and construction. QFD is used to carry the VOC to product design/development and through to manufacturing. This capability of QFD can provide the construction industry with the same opportunity to carry the VOC through design and construction of new buildings.

Several studies modified the traditional QFD approach for use in the construction industry. Many were validated on small or singular construction projects. Further research to adapt the QFD methodology to the design-build project delivery method should be conducted. These projects should involve complex buildings with diverse customers. In addition, there is some overlap between construction management and project management. Research comparing the use of these methodologies with QFD in the construction industry may provide insight for complex construction projects.

QFD has been used successfully in the design-bid-build construction delivery process. The design-build delivery method has similarities to the concurrent engineering methods used in product development and manufacturing. Further research to adapt this methodology to the designbuild project delivery method should be conducted.

\section{References}

Abdul-Rahman, H., Kwan, C. L., \& Woods, P. C. (1999). Quality function deployment in construction design: application in low-cost housing design. International Journal of Quality \& Reliability Management, 16(6), 591-605.

Ahmed, S., Sang, L.P., \& Torbica, Z. (2003). Use of quality function deployment in civil engineering capital project planning. Journal of Construction Engineering and Management, 129, 358-368.

Caulfield, J. (2015). Construction will outpace worldwide GDP growth over the next 15 years. Retrieved from http://www.bdcnetwork.com/ construction-will-outpace-worldwide-gdp-growth-over-next-15years.

Chan, L.K., \& Wu, M.L. (2002). Quality function deployment: a comprehensive review of its concepts and methods. Quality Engineering, 15, 23-35.

Clausing, D. (1994). Total quality development: a step-by-step guide to world class concurrent engineering. New York: The American Society of Mechanical Engineers.

Cristiano, J.J., Liker, J.K., \& White, C.C. (2000). Customer-driven product development through quality function deployment in the U.S. and Japan. Journal of Product Innovation Management, 17, 286308.

Cudney, E., \& Agustiady, T. (2016). Design for six sigma: a practical approach through innovation. New York: CRC Press.

Cudney, E., Elrod, C., \& Uppalanchi, A. (2012). Analyzing customer requirements for the American society of engineering management using quality function deployment. Engineering Management Journal, 24, 47-57.

Delgado-Hernandez, D.J., Bampton, K.E., \& Aspinwall, E. (2007). Quality function deployment in construction. Construction Management and Economics, 25, 597-609.

Denyer, D., \& Tranfield, D. (2009). Producing a systematic review. In Buchanan D. A., \& Bryman A. (Eds.), The sage handbook of organization research methods (pp. 671-689). Cornwall: Sage Publications Ltd.

Dikmen, I., Birgonul, M.T., \& Kiziltas, S. (2005). Strategic use of quality function deployment in the construction industry. Building and Environment, 40, 245-255.

Eldin, N., \& Hikle, V. (2003). Pilot study of quality function deployment in construction projects. Journal of Construction Engineering and Management, 129, 314-329.

Ezzell, J., Cudney, E., Mazur, G., \& Phelps, J. (2016). One size does not fit all: utilizing quality function deployment for course design. Quality Management Journal, 23, 37-53.

Gillis, W., \& Cudney, E. (2014). A new methodology for eco-friendly construction-utilizing quality function deployment to meet LEED requirements. In Azevedo, S., Brandenburg, M., Carvalho, H., \& Cruz-Machado, V. (Eds), Eco-Innovation and the development of business models: lessons from experience and new frontiers in theory and practice (pp. 245-273). Berlin Heidelberg: Springer.

Gillis, W., \& Cudney, E. (2015a). A standard for the commissioning process. Frontiers of Engineering Management, 2, 39-51.

Gillis, W., \& Cudney, E. (2015b). A methodology for applying quality function deployment to the commissioning process. Engineering 
Management Journal, 27, 177-187.

Global Construction Perspectives and Oxford Economics. (n.d.). Global Construction 2030. Retrieved from http://www.globalconstruction2030.com/.

Hauser, J.R., \& Clausing, D. (1988). The house of quality. Harvard Business Review, 66, 63-73.

IHS. (2013). Global executive summary. Retrieved from https://www.ihs. com/pdf/IHS_Global_Construction_ExecSummary_Feb2014_1408 52110913052132.pdf.

Jeong, M., \& Oh, H. (1998). Quality function deployment: an extended framework for service quality and customer satisfaction in the hospitality industry. International Journal of Hospitality Management, 17, 375-390.

Karsak, E.E., Sozer, S., \& Alptekin, S.E. (2003). Product planning in quality function deployment using a combined analytic network process and goal programming approach. Computers \& Industrial Engineering, 44, 171-190.

Lee, D., \& Arditi, D. (2006). Total quality performance of design/build firms using quality function deployment. Journal of Construction Engineering and Management, 132, 49-57.

Liu, J., \& Zeng, F. (2012). Research on conceptual design method for marine power plant based on QFD. Computational Intelligence and Design (ISCID), 2012 5th International Symposium on (pp. 246249), Hangzhou.

Mallon, J.C., \& Mulligan, D.E. (1993). Quality function deployment-a system for meeting customers' needs. Journal of Construction Engineering and Management, 119, 516-531.

Masoudi, A., Cudney, E., \& Paryani, K. (2013). Customer-driven hotel landscaping design: a case study. International Journal of Quality \& Reliability Management, 30, 832-852.

Mazur, G. (1996). The application of quality function deployment to design a course in total quality management at the university of Michigan College of Engineering. Proceedings of the International Congress on Quality, Yokohama, Japan.

Paryani, K., Masoudi, A., \& Cudney, E. (2010). QFD Application in hospitality industry - a hotel case study. Quality Management
Journal, 17, 7-28.

Romeo, J., Smith, A., Chotipanich, S., \& Pitt, M. (2014). Awareness and effectiveness of quality function deployment in design and build projects in Nigeria. Journal of Facilities Management, 12, 72-88.

Sahney, S., Banwet, D.K., \& Karunes, S. (2006). An integrated framework for quality in education: application of quality function deployment, interpretive structural modelling and path analysis. Total Quality Management \& Business Excellence, 17, 265-285.

Shi, Q., \& Xie, X. (2009). A fuzzy-QFD approach to the assessment of green construction alternatives based on value engineering. Management and Service Science, 2009. MASS '09. International Conference on (pp. 1-6), Wuhan.

Singh, R., Elrod, C., \& Cudney, E. (2012). Comparative analysis of quality function deployment methodologies: a case study analysis. Quality Management Journal, 19, 7-23.

Stanley, S., Elrod, C., Cudney, E., \& Fisher, C. (2015). Empirical study utilizing QFD to develop an international marketing strategy. Sustainability, 7, 10756-10769.

Tranfield, D., Denyer, D., \& Smart, P. (2003). Towards a methodology for developing evidence-informed management knowledge by means of systematic review. British Journal of Management, 14, 207-222.

Wood, L.C., Wang, C., Abdul-Rahman, H., \& Abdul-Nasir, N.S.J. (2016). Green hospital design: Integrating quality function deployment and end-user demands. Journal of Cleaner Production, 112, 903-913.

Yang, Y. Q., Wang, S. Q., Dulaimi, M., \& Low, S. P. (2003). A fuzzy quality function deployment system for buildable design decisionmakings. Automation in Construction, 12, 381-393.

Yuventi, J., \& Weiss, S. (2013). Value sensitivity of quality function deployment approaches in systems engineering-driven construction projects. Systems Conference (SysCon), IEEE International (pp. 847852), Orlando, FL.

Zairi, M., \& Youssef, M.A. (1995). Quality function deployment: a main pillar for successful total quality management and product development. International Journal of Quality \& Reliability Management, 12, 9-23. 